\section{Toshiba sets up UK chip lab}

\section{London \& Tokyo}

ToshiBA, the Japanese electronics company, is opening a semiconductor research centre in Cambridge, England, in January 1991, its first European basic research laboratory.

The centre is one of a series of Britishbased research laboratories being set up by Japanese electronics companies, filling a vacuum in British semiconductor research left after recent cutbacks by British and European companies (see Nature 347, 415; 4 October 1990). Hitachi already has a seven-strong research group working within the University of Cambridge's Cavendish Laboratory, and Sharp, which recently opened a 12-man laboratory in Abingdon near Oxford, is planning to expand into a large centre in the Oxford Science Park in 1992.

The Toshiba Cambridge Research Centre has an initial research and development budget of $£ 640,000$ a year, and will concentrate on quantum effect physics which may underpin the next generation of miniaturized electronic devices. Michael Pepper, professor of physics at the Cavendish Laboratory, will be the centre's director, and says the ten researchers he is recruiting will collaborate closely with the university. Sei-ichi Takayanagi, senior vice president of Toshiba, says the centre's staff will be allowed to publish their results freely, and any patentable technology will belong to the centre.

Japanese companies are keen to invest in research in Britain to marry British expertise in basic research with the Japanese flair for technological development. A longer-term aim is to strengthen the vertical integration of their operations in Europe from basic research to production. Toshiba also plans to establish product development laboratories at some European production facilities.

Another motivation is Toshiba's desire to collaborate in European Communities (EC) research projects. Takeo Fujii, European general manager for Toshiba, says that the company has approached European Commission officials, but has not yet discussed any "concrete programmes".

As a subsidiary of Toshiba registered in a European country, the new centre would be eligible to participate in EC research projects. But the problem will be finding European companies willing to collaborate with a Japanese-owned company. Some European computer companies are now questioning their continued collaboration with the British company ICL in a number of ESPRIT information technology projects, after the sale of a majority holding in ICL to the Japanese company Fujitsu. Toshiba officials are aware of the potential problems, and stress that their centre will be devoted entirely to basic research, which should be less commercially sensitive.

Peter Aldhous \& David Swinbanks

\section{OFFSHORE AIRPORT}

\section{That sinking feeling . . .}

\section{Tokyo}

A RED-faced Japanese official in charge of plans to build the world's largest manmade island in the Seto Inland Sea off Osaka had to admit to the foreign press on Monday that the opening of a new international airport on the island will be delayed because the island is sinking into underlying mud much faster and further

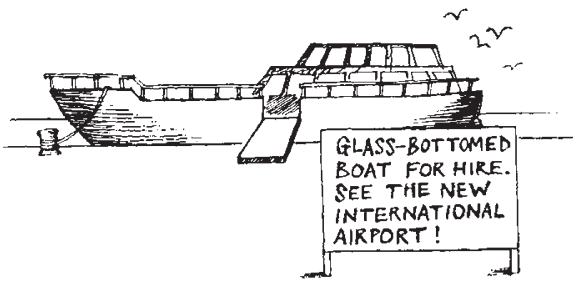

than had been predicted (see Nature 347, 7; 1990).

Yoshio Takeuchi, president of the Kansai International Airport Co. (KIAC) announced with "great regret" that the scheduled opening of the airport in March 1993 will postponed by "about 15 months". The delay is particularly embarrassing because foreign construction companies were shut out of the lucrative reclamation phase of the $\$ 11,000$-million airport project because of (among other reasons) their "inexperience" in dealing with the soft marine sediments around the coast of Japan.

KIAC took extraordinary measures to strengthen the sea bed at the construction site in 18-20 metres of water $5 \mathrm{~km}$ off the coast when reclamation work began in 1987. But the company failed to predict correctly the amount of compaction in the much deeper underlying Pleistocene layers of sediment at 20-400 metres below the sea floor as the newly emerging 511hectare artificial island presses down with a force of 40 tons per square metre.

Before construction, KIAC estimated that subsidence in the Pleistocene layer would be only 1-2 metres but actual subsidence will be more like 5-6 metres according to measurements of settlement of the island. As a result, an extra 3.5 metres of fill will have to be added to the island at a cost of about $\$ 20,000$ million $(\$ 150$ mil-

\section{Lab stocks to go}

London

THE last remaining stocks of the smallpox virus should be destroyed by the end of 1993, after US and Soviet laboratories have finished sequencing the smallpox viral genome. Frozen viruses are now kept only at the Centers for Disease Control in Atlanta and the Research Institute for $\mathrm{Vi}$ ral Preparations in Moscow. The thaw in superpower relations is a factor in the decision to destroy the stocks - both countries had feared that the virus could be used in biological warfare.

Smallpox was eradicated outside the laboratory in 1977, after a decade-long campaign by the World Health Organisation. A single case occurred in 1978, through a laboratory accident in Birmingham, in the British Midlands.

Peter Aldhous

\section{BSE}

\section{Maternal transmission in antelope}

\section{London}

AgRICULTURE ministry pathologists have confirmed that an 18-month-old kudu from London Zoo, never fed the animal feed thought to contain the infective agent of bovine spongiform encephalopathy (BSE), died of a BSE-like disease. The only source for infection seems to be the antelope's mother, which died of a spongiform encephalopathy in 1989. This is the first time a BSE-like disease has been shown to be transmitted from mother to offspring, except from in scrapie-infected sheep, where maternal transmission is common (see Nature 348, 380; 29 November 1990).

The finding increases speculation that maternal transmission may also occur in BSE-infected cattle. But an agriculture ministry spokesman says that farmers will still not be advised to avoid breeding from the offspring of BSE cases. Even if maternal transmission of BSE is possible in cattle, it may not prolong the epidemic significantly if it is a reasonably rare occurrence.

Peter Aldhous

lion) to keep the airport above sea level.

Furthermore, the foundations of the Italian-designed airport terminal building will have to be reinforced with iron ore and the two wings of the terminal will be mounted on hydraulic jacks to compensate for differential subsidence of the wings after the airport opens.

But by far the biggest cost of the delay will be interest payments on the huge loans taken out by KIAC to finance construction. All in all, the delay is expected to cost more than $¥ 100,000$ million ( $\$ 750$ million) . . . plus a certain loss of face. 